\title{
Margaret McCartney: When organ donation isn't a donation
}

\author{
Margaret McCartney general practitioner
}

Glasgow

\begin{abstract}
"Soft opt-out boosts donation in Wales," wrote the BMA. ${ }^{1}$ "'Dozens saved' in six months by Welsh deemed consent organ donation system," said the Guardian. ${ }^{2}$ Should the rest of the UK follow what Wales started in December 2015: a system of opt-out organ donation?

The rest of the UK requires consent for organ donation, either by the dead person having pre-empted the decision by joining the donor register or by family consent. Wales uses a "soft" opt-out, meaning that it's not intended to be legally enforced and that potential situations where doctors remove organs for transplant directly against the surviving family's wishes will not occur.
\end{abstract}

Has it been effective? The most recent available figures, from the first three quarters of 2016-17, show a small decrease in deceased donors since the same period the previous year. ${ }^{3}$ Although variability is to be expected, they don't show the obvious increase in donations the headlines suggest.

In fact, opt-out legislation may do more harm than good. This law is present but not enforced, so the point of it must be debated. Will it make people think more about organ donation? Possibly: certainly, it's triggered a small avalanche of people who heard the publicity about the new law and chose to opt out. One in 20 Welsh adults has opted out after the new process, compared with none before. I consider this a potential harm, because some or many of those opting out may have been willing to donate freely but not under uncertain legislation. It means that the number of potential donors has shrunk by $5 \%$. It may mean unease with doctors, donation, or death. Trust may decrease as a result.

Above all, what is the effect of presuming donation?

A forced, presumed, or expected gift is not a gift

Discussions hover in England and Scotland about passing new laws to emulate Wales. Although I fully support organ donation, there are reasons to be cautious about an opt-out law. If it doesn't achieve the desired effect, it's pointless.
It's worth noting that, in Spain-the high achiever of the organ donating world-no increase in donations was noted until 10 years after an opt-out law was passed, when well staffed transplant coordinating teams were instigated. Additionally, Spain has organ donor cards that citizens can carry but no register of people who have opted either in or out. ${ }^{4}$ The systems are thus quite different.

Furthermore, internationally, any rise in deceased donation tends to be accompanied by a decrease in living kidney donations. ${ }^{5}$

But, above all, what is the effect of presuming donation? A forced, presumed, or expected gift is not a gift. A striking feature of families who have allowed donation has been the desire to help others and the feeling that some shred of good has come out of their profound loss. If the sum of free will to donate is decreased, how can this benefit be realised to the same extent?

Competing interests: See www.bmj.com/about-bmj/freelancecontributors/margaret-mccartney.

Provenance and peer review: Commissioned; not externally peer reviewed.

Follow Margaret on Twitter, @mgtmccartney

1 BMA. Organ donation. 24 Feb 2017. https://www.bma.org.uk/collective-voice/policy-andresearch/ethics/organ-donation.

2 Morris S. "Dozens saved" in six months by Welsh deemed consent organ donation. Guardian 14 Jun 2016. https://www.theguardian.com/society/2016/jun/14/wales-deemedconsent-organ-donations-increase-transplants.

3 NHS Blood and Transplant. Organ donation and transplant activity Wales. Jan 2017. https://nhsbtdbe.blob.core.windows.net/umbraco-assets/1518/wales.pdf.

4 Fabre J, Murphy P, Matesanz R. Presumed consent: a distraction in the quest for increasing rates of organ donation. BMJ 2010;356:c4973. doi:10.1136/bmj.c4973 pmid: 20959281.

5 Shepherd L, O'Carroll RE, Ferguson E. An international comparison of deceased and living organ donation/transplant rates in opt-in and opt-out systems: a panel study. $B M C$ Med 2014;356:131. doi:10.1186/s12916-014-0131-4 pmid:25285666.

Published by the BMJ Publishing Group Limited. For permission to use (where not already granted under a licence) please go to http://group.bmj.com/group/rights-licensing/ permissions 